\title{
Historicizing the Present in 9/11 Fiction
}

\author{
Todd Kuchta
}

\section{Synopsis}

Reconfiguring the debate on the historical efficacy of postmodern fiction, novels inspired by 9/11 seek to view the present itself as history. McEwan's Saturday, DeLillo's Falling Man, and Hamid's Reluctant Fundamentalist attempt to move beyond the view of history-as-text. Rather than evoking "the presence of the past," they present characters trying to situate themselves in a new historical reality. Žižek's account of Lacan illuminates DeLillo's attempt to historicize the present, while McEwan gestures toward Foucault's view of the present as exit. Only Hamid engages the historical potential of the present.

\section{Biography}

Todd Kuchta is associate professor of English at Western Michigan University and the author of Semi-Detached Empire: Suburbia and the Colonization of Britain, 1880 to the Present (University of Virginia Press, 2010). He is working on terrorism and representations of history in modern British, postcolonial, and contemporary U.S. fiction.

\section{Essay}

Near the end of lan McEwan's Saturday, Henry Perowne sits in a London traffic jam caused by the historic 2003 protest against the impending invasion of Iraq. As the narrator tells us, Perowne "tries to see [this moment], or feel it, in historical terms. . . . But he can't quite trick himself into it. He can't feel his way past the iron weight of the actual. ... He doesn't have the lyric gift to see beyond it" (168). Like Perowne, the novels inspired by $9 / 11$ and the global "war on terror" repeatedly attempt to view our present with a perspective Fredric Jameson calls historicity. More than mere historical context, historicity involves "a perception of the present as history ... a relationship to the present which somehow defamiliarizes it and allows us that distance from immediacy which is at length characterized as historical perspective." Jameson's working hypothesis in Postmodernism is that today such a perspective is more difficult to achieve than in heyday of the historical novel, "when contemplation of the past seemed able to renew our sense of our own reading present" (284). The struggle with historicity is not unique to $9 / 11$ fiction, but in what follows I want to suggest that McEwan's Saturday, Don DeLillo's Falling Man, and Mohsin Hamid's The Reluctant 
Fundamentalist manifest this struggle differently than in the classic debate on postmodern fiction and history. That debate approached history as fundamentally textual, be it Jameson lamenting contemporary historical consciousness as a simulacrum of the past, or Linda Hutcheon celebrating the postmodern awareness that history itself is a narrative construct. ${ }^{1}$ DeLillo, McEwan, and Hamid move beyond the view of history as a text or competing set of narratives. Rather than evoking "the presence of the past," which lives on as a discursive precondition of our current experience, or as the moment of a novel's narration, their works present characters hyperconsciously trying to situate themselves in a new historical reality. Unlike classic postmodern historiographic metafiction, these novels attempt not to historicize from within the present moment, but to historicize the present moment itself. ${ }^{2}$

The supposed "return to history" has been a staple of popular and scholarly discourse on $9 / 11$, whether to frame the event as an unpredictable historical rupture or to challenge such views as exceptionalist disavowals of geopolitical reality. ${ }^{3}$ But questioning the popular refrain that everything changed on 9/11 doesn't preclude the possibility that the refrain itself has altered our sense of time and history. Consider the focus on minute slivers of time since 9/11: the minute-by-minute account of the attacks and their aftermath, which structures most TV documentaries and opens the 9/11 Commission Report; the excruciating footage of George W. Bush-waiting -in a Florida classroom; the cable news crawl that began to cross our screens and the ticking time bomb scenarios that filled our newscasts and popular narratives. Complicating such heightened immediacy was a new vision of the longue durée, as our sense of the future was recalibrated for a perpetual war on terror, an endless battle of world-historical proportion. Meanwhile, we adjusted to a new normal that made "vigilance" our best defense in the present. Fictional responses to 9/11 have foregrounded this altered sense of time and history, yet as a whole the works have been found lacking -if not complicit with inept state responses to terror. One critic, echoing the 9/11 Commission Report, cites such novels for their "failure of the imagination" (Rothberg 153). Another dubs McEwan "the Homeland Security Chief of the Novel," comparing his treatment of the present to distributing "duct tape and plastic sheeting" as protection against an "unpredictable ... new world order" (Hadley 97). ${ }^{4}$

Before turning to DeLillo and McEwan, I want to suggest how an attempt to historicize the present manifests itself in the first U.S. novel on 9/11, Jonathan Safran Foer's Extremely Loud and Incredibly Close. ${ }^{5}$ The novel recounts the quest of precocious nineyear-old Oskar Schell to unlock the secret of a key left behind by his father, who died in the $9 / 11$ attacks. The novel uses multiple narrators, integrates visual texts, and embraces postmodern contingency-its incredulity toward metanarrative reflected in the father's responses to Oskar's questions about the universe: "there doesn't have to be a reason" (13). In the mode of historiographic metafiction, the novel interweaves accounts of Hiroshima and Dresden that foreground their status as texts. But these gestures belie the novel's fundamentally nostalgic vision of history, its attempt to retrieve a pretraumatic past imagined as innocent and whole. This desire is reflected in the way that characters fetishize frozen moments of time. Oskar's grandfather, who suffers aphasia and communicates through notebooks, compares his writing to "a loaf of black bread 
that I left out one night[:] the next morning I saw the outline of the mouse that had eaten through it, I cut the loaf into slices and saw the mouse at each moment" (113). Oskar's grandmother, engaged in an autobiography, succeeds where Tristram Shandy fails by bringing her text up speed with the present: "I just made it up to the present moment," she declares upon finishing. "Just now. I'm all caught up with myself" (120). More than mere historical records, these are attempts to historicize the present, to suspend its fluidity and read the passage of time like the frames of a film. But the project is undercut by the form these attempts take. In some ways, Oskar appears more equipped than his elders to view the present as history. Near the end of the novel, looking out over New York from atop the Empire State Building, he declares "you can see what it's really like, instead of how it feels when you're in the middle of it" (245). But this insight is shortlived, as the novel's closing lines and famed flip-book confirm. For all its reputed hokeyness, the flip-book of the falling man in reverse may come closer than anything else in the novel to historicizing the present by coordinating individual moments with the passage of time in order to satisfy a demand in the present. But the result is a mere reversal of history, a return to an impossible time when "we would have been safe" (326).

If Foer would historicize the present by resurrecting a frozen or inverted past, the very title of Don DeLillo's Falling Man acknowledges the movement of the present, in this case its "unavoidable downward motion" (Versluys 35). The novel begins on 9/11, with Keith Neudecker fleeing the north tower before it collapses and returning, unintentionally, to his former apartment, where his estranged wife and son still reside. DeLillo depicts Keith's initial response to 9/11 with an avalanche of uncoordinated conjunctions reminiscent of Hemingway. The novel opens: "It was not a street anymore but a world, a time and a space, of falling ash and near night. He was walking north though rubble and mud and..." (3, my emphasis). The novel recurrently depicts characters trying to situate themselves in this new time and space, to account for what appears directly before them. This is exemplified by a man who stands next to Keith at the perimeter of the twin tower rubble days after the attacks and repeats into his cell phone: "I'm standing here" (25). ${ }^{6}$

As this suggests, DeLillo attempts to historicize the present through repetition, a form of repetition that can be approached through Slavoj Žižek's account of what Lacan called the two deaths. For Lacan, any death or traumatic event must occur twice to be historicized. The second death is required so that the initial, inexplicable trauma-the first death-can begin to register itself meaningfully in the existing symbolic network. "When an event erupts for the first time," Žižek explains, "it is experienced as a contingent trauma, as an intrusion of a certain non-symbolized Real." This initial trauma Žižek calls a "non-historical place," one "which cannot be symbolized" until it is "retroactively produced" through repetition (Sublime 150). It is only through repetition that the event "finds its place in the symbolic network" (Sublime 64-65). In doing so, the second death makes possible a historical interpretation of the initial, hitherto unrepresentable trauma. Žižek and others have drawn on Lacan's notion of two deaths to read 9/11 as a symbolic repetition of the fall of the Berlin Wall, which enabled us to begin historicizing the post-Cold War era that Francis Fukuyama prophesied as "the end 
of history." As Phillip Wegner explains, "it [was] only with the fall of the twin towers that the destruction of the symbolic universe of the Cold War [was] finally accomplished ... in ways not possible in the immediate, uncertain aftermath of the Cold War" (9). ${ }^{7}$ More recently, Žižek has described the 2008 financial crisis as an economic repetition of 9/11's political trauma, "since the collapse of the liberal-democratic political utopia on 9/11 did not affect the economic utopia of global market capitalism." The financial crisis thus finds its "historical meaning" for Žižek as "the end of the economic face of Fukuyama's dream," whose first death took place on 9/11 (First 5).

Falling Man enacts the pattern of Lacan's two deaths, even as the novel and its characters fail to draw historical significance from the symbolic repetition of traumatic events. Consider a crucial scene when Keith and his wife Lianne watch a video replay of the planes striking the twin towers. "It still looks like an accident, the first one," Keith says. "I'm standing here thinking it's an accident." "Because it has to be," Lianne replies. "The way the camera sort of shows surprise." "But only the first one," they repeat to each other. "By the time the second plane appears," Keith adds, "we're all a little older and wiser" (135). Note the complexity of repetitions here-the reunited couple replaying the attack, the second plane following the first into the twin towers, Lianne reexperiencing the trauma of Keith's apparent death ("there he is"), Keith echoing the man on the cell phone ("I'm standing here"), and the couple repeating to each other that "only the first" plane looked like an accident. These repetitions reinforce what Keith and Lianne and the camera itself seem to intuit: that the second crash has created a space within the new symbolic order for the first crash to be assimilated. At the same time, this moment fails to initiate the historical meaning provided by the second death. Even though the second plane makes them "a little older and wiser," the contingent trauma of the first plane lingers on, overshadowing the knowledge of the event that the second plane should impart.

The novel's failure to historicize the present through the second death is also illustrated by the titular falling man, David Janiak, a performance artist whose headfirst dives reenact $9 / 11$ victims plunging from the twin towers. A disciple of avant-garde theatre, Janiak seems to stage his falls to shock unwitting train passengers with a form of Brechtian alienation-effect. ${ }^{8}$ Just as Janiak relies on the most basic safety gear, avoiding bungee cords or pulleys that would "absorb the shock of longer falls" (220), he seems intent on sustaining shock in his unsuspecting spectators rather than cushioning the traumatic blow. Janiak refuses to disclose anything that would clarify his purpose: none of his falls are "announced in advance," none are "designed to be recorded by a photographer," and Janiak denies all opportunities to discuss his intentions $(220,222)$. If anything, he seems bent on reappropriating the media's monopoly over the traumatic event, returning its symbolic assimilation to the individual or community level. Reading Janiak's obituary —he dies of natural causes - three years after she witnessed one of his performances, Lianne herself becomes an archive of the event: "There were no photographs of that fall. She was the photograph. ... That nameless body coming down, this was hers to record and absorb" (223). But like the video camera that "sort of shows surprise" when the first tower is struck, Lianne records Janiak's fall without assimilating it into a historical account. Janiak elicits a shock that symbolically repeats 
the trauma of $9 / 11$ yet resists creating a frame for interpretation or closure. Unlike Foer, whose concluding flip-book would undo the trauma of the falling man's death, DeLillo's falling man repeats a past that is not secure, that cannot be recovered in its pretrauamtic wholeness. At the same time, Lianne's experience suggests there is no symbolic closure, no historicization to be gained from Janiak's symbolic repetition of $9 / 11{ }^{9}$

McEwan's Saturday is also preoccupied with attempting to historicize the present-in this case, the day of the largest political demonstration in London's history. Narrated from the perspective of Henry Perowne, "an habitual observer of his own moods" (5), Saturday recalls the hyperconscious temporal and spatial situatedness of DeLillo's characters. And to some extent, Saturday also recalls the failed second deaths of Falling Man. Perowne's early morning view of a fiery jetliner echoes the 9/11 attacks, but the uneasy feeling it leaves him never receives proper closure from repeated "crashes" throughout the day-a collision with a colleague on the squash court, and, more significantly, a fender bender that results in a domestic break-in and threats of violence against his family. Yet in discussing Saturday, I want to suggest that Michel Foucault's view of the present tells us more about the limits of this novel's historical perspective.

Foucault's inspired phrase "the history of the present" derives from Discipline and Punish (31), but his most sustained thoughts on this phrase come in his late work on Immanuel Kant. Foucault claims that in his brief essay "What is Enlightenment?" Kant invents a new orientation toward the present: unlike the Cartesian question "Who am I," which applies to anyone at any time, Kant asks "What are we? in a very precise moment of history" ("Subject" 133-34). Moreover, whereas earlier philosophers viewed the present as a distinct era (Plato), a herald of the future, (Augustine), or a transition (Vico), Kant imagined the present "in an almost entirely negative way, as an Ausgang, an 'exit,' a 'way out' . . . . He is not seeking to understand the present on the basis of a totality or of a future achievement. He is looking for a difference: What difference does today introduce with respect to yesterday?" ("What" 44-45). Kant's "negative" view of the present as exit or difference chimes with Foucault's notion genealogy, the historical approach that unravels the seeming inevitability of the present by looking for alternate lines of development in our past. ${ }^{10}$ But Foucault also discovers in Kant a crucial ethos toward the present. Updating the Enlightenment's self-imposed task-"Dare to know!"Foucault derives from Kant "a critical ontology of ourselves," ourselves understood as historically distinct rather than some ahistorical form of humanity. The ontology of ourselves requires "an attitude, an ethos ... in which the critique of what we are is at one and the same time an analysis of the limits imposed on us and an experiment with the possibility of going beyond them" ("What" 56). For Foucault, this ethos involves challenging the historical forces that have made us what we are. Considering how to challenge disciplinary mechanisms in the present, Foucault suggests "Maybe the target nowadays is not to discover what we are but to refuse what we are" ("Subject"134).

Saturday can be read in light of Foucault's view of the present. Perowne is an updated disciple of the Enlightenment who praises science, reason, self-determination, and 
freedom of thought; he even lives in a Regency façade. At the same time, Perowne's thoughts are reminiscent of Foucault's desire to historicize the present by specifying the difference that today introduces with respect to yesterday. ${ }^{11}$ "And now, what days are these?" he asks himself early in the novel (4), and he remains intent on diagnosing this new moment when "airliners look different in the sky" and "misunderstanding is general all over the world" $(16,39)$. Yet Perowne also falters in his task, veering between a view of the present as exit and what Nietzsche would call monumental history. Sitting in a late-afternoon traffic jam, Perowne:

he tries to see it, or feel it, in historical terms, this moment ... when the unprecedented wealth of masses at serious play in the unforgiving modern city makes for a sight that no previous age can have imagined. Ordinary people! Rivers of light! He wants to make himself see it as Newton might, or his contemporaries Boyle, Hooke, Wren, Willis-those clever, curious men of the English Enlightenment .... Mentally he shows it off to them. . . . All this teeming illumination would be wondrous if only he could see it through their eyes. But he can't quite trick himself into it. . . . He doesn't have the lyric gift to see beyond it." (168)

While he attempts to see the present from the perspective of his Enlightenment heroes, Perowne is either unconvinced by his own paeans to the present as a fulfillment of their values or lacking the "lyric gift" of his daughter and father-in-law, poets both. Indeed, when his dyspeptic father-in-law John Grammaticus arrives for a family gathering, Perowne finds him looking at the British Telecom Tower, wondering how Robert Adam, the neoclassical architect who designed Perowne's square, would see it. Perowne responds with characteristic optimism: "All that glass, and the unsupported height, would have amazed him. So would the electric light." But Grammaticus is having none of it: "Adam would have been stunned by the ugliness of glass thing. No human scale. . . . It would have put fear in his heart. If that's going to be our religion, he'd've said to himself, then we're truly fucked" (197).

This face-off reveals the limits of Saturday's attempts to historicize the present. While Grammaticus and Perowne both attempt to see the present through the eyes of the Enlightenment, McEwan can broker no compromise between "rivers of light" and "we're truly fucked." In this sense, Saturday exhibits what Foucault considers "one of the most harmful habits ... in modern thought," namely, "the analysis of the present as being precisely, in history, a present of rupture," whether as a high point or low point of history. "I think we should have the modesty to say to ourselves that ... the time we live in is not the unique or fundamental or irruptive point in history." As Foucault puts it, we must view the present as both "a time like any other" and "a time that is never quite like any other" (Essential 93-94).

If Saturday is limited as a Foucaultian history of the present, I want to close with a novel that resonates more powerfully with Foucault's view of the present as both an exit and an obligation to refuse what we are. Mohsin Hamid's 2007 novel The Reluctant Fundamentalist is narrated by Changez, a Pakistani mimic man who wins a scholarship 
to Princeton then lands a job with a prestigious U.S. financial firm, but grows increasingly resentful of America following 9/11. Eventually returning to Lahore, Changez becomes a university lecturer and admits to vague connections with jihadist students. Changez narrates his tale in the second person to an American male, an undercover agent or government assassin. Though Changez offers himself as a courteous host to the American, and appears intent on demonstrating the good will of Pakistanis, his tale of disillusionment with the United States casts a shadow over the novel. Having safely escorted his American listener to his hotel in the novel's closing pages, Changez attempts to shake his hand, but a sinister figure-a surly waiter from earlier that evening - approaches. The American reaches into his jacket and Changez attempts to forestall the inevitable, politely reminding him of their "shared intimacy," trusting that the "glint of metal" he sees must only be "the holder of your business cards" (184).

The episode surely ends in gunfire, but the novel's suspension before this moment can erupt is a powerful gesture towards historicizing the present. "It seems an obvious thing to say," Changez tells the American before the other man closes in, "but you should not imagine that we Pakistanis are all potential terrorists, just as we should not imagine that you Americans are all undercover assassins" (183). Despite this caveat, it's clear that Changez is in some way involved with potentially dangerous fundamentalists, and the American is a government agent. At the same time, Hamid suggests that we refuse the roles we inhabit and play our hands differently. Hamid's question becomes: given what our histories have made us, how do we now respond? Like a Foucaultian history of the present, The Reluctant Fundamentalist asks us to grasp our current moment as an opportunity for an exit-not a refusal to engage with the present, but what Foucault calls "an analysis of the limits imposed on us and an experiment with the possibility of going beyond them" ("What" 56). The novel does not attempt, like Foer, to freeze or rewind history to capture some lost, illusory innocence. Nor does it require, like DeLillo or McEwan, the symbolic repetition of an originating trauma, or recourse to an idealized or demonized view of the present in relation to the past. Unlike DeLillo and McEwan, Hamid reminds us of the historical potential of the present-and of our ability to alter or exit that history before it's too late.

\section{Notes}

${ }^{1}$ Jameson claims that postmodernism effaces "the past as 'referent' . . leaving us with nothing but texts," so that "we are condemned to seek History by way of our own pop images and simulacra of that History" (Postmodernism 18, 25). Hutcheon, in turn, argues that postmodern narrative "contest[s] the very possibility of ever being able to know the 'ultimate objects' of the past," thereby recognizing that "the social, historical, and existential 'reality' of the past is discursive reality when it is used as the referent of art" (24). 
${ }^{2}$ Mark Currie notes that narratology has long viewed "the present as a place from which we continuously revise stories about the past, and [has been] much less attentive to the relationship between storytelling and the mode of continuous anticipation in which we attach significance to present moments" (6). Currie includes Hutcheon's historiographic metafiction among those "retrospective' models of narrative" he seeks to challenge (6).

${ }^{3}$ For claims countering the unpredictability of $9 / 11$, see Derrida (Borradori 91) and Žižek (Welcome 15-16). On 9/11 keywords (e.g., "ground zero" and "homeland") as a return of repressed U.S. national experiences with the Cold War and immigration, see Kaplan.

${ }^{4}$ In a similar vein, novelist John Banville claims Saturday reads as if Tony Blair had "appoint[ed] a committee to produce a 'novel for our time."' For more measured critiques of 9/11 fiction, see Gray and also Eaglestone, who claims that McEwan and Foer fail to fulfill the novel's purpose as a genre, which is "to encounter and to think through, in singular and irreplaceable ways, 'how we are' and 'how the world is for us'" (366).

${ }^{5}$ Foer's novel was released in the U.S. in April 2005; McEwan's Saturday appeared in the U.K. in January 2005.

${ }^{6}$ In his essay "In the Ruins of the Future," DeLillo describes standing next to such a figure himself when he visited the rubble of the twin towers ten days after 9/11.

${ }^{7}$ Wegner builds on Žižek's claim that 9/11 brought an end to Fukuyama's "end of history" thesis, which replaced communism's failed utopian project with a "utopia of global capitalist liberal democracy." Žižek argues that "It is crucial to perceive how the 'end of utopia' repeated itself in a self-reflexive gesture: the ultimate utopia was the very notion that, after the end of utopias, we were at the "end of history"' (Iraq 122-23).

${ }^{8}$ With the exception of an essay by John Duvall on a real-life analogue to Janiak, this character has received relatively little scholarly attention. For a meditation on the links between $9 / 11$ and avant-garde art, see Schechner.

${ }^{9}$ Critics disagree over whether DeLillo facilitates or resists the work of mourning 9/11, but they tend to concur that his narratives challenge media accounts of the tragedy. Kauffman claims that "In the Ruins of the Future" provided a counter-narrative to the media transformation of tragedy into spectacle, adding that "the counter-narrative's provenance is the realm of the unspeakable, the unfathomable. It does the work of mourning" (354). In contrast, Versluys describes Falling Man as "pure melancholia without the possibility of mourning" and claims the novel's "reenactment of trauma ... allows for no accommodation of resolution" (20). Nevertheless, Versluys continues, DeLillo's use of falling man as a central image "provides a counter-discourse to the prevailing nationalistic" rhetoric after $9 / 11$, which sought to transform vulnerability into triumphant profiles in courage (23). Also see Duvall.

${ }^{10}$ As Gary Gutting suggests, Foucault's "genealogical method can be understood in terms of his desire to write histories of the present" (12). "Whereas much traditional 
history tries to show that where we are is inevitable, given the historical causes revealed by its account, Foucault's histories aim to show the contingency-and hence surpassability —of what history has given us. Intolerable practices and institutions present themselves as having no alternative. ... Foucault's histories aim to remove this air of necessity by showing that the past ordered things quite differently and that the processes leading to our present practices and institutions were by no means inevitable" (Gutting 10).

${ }^{11}$ This, despite McEwan's underhanded allusion to Foucault: Perowne recalls his daughter at Oxford, "dazzled by some handsome fool of a teacher" and "try[ing] to convince her father that madness was a social construct" (92). On the same page, Perowne is down the street from a pub named after panopticon designer Jeremy Bentham.

\section{Works Cited}

Banville, John. "A Day in the Life." Rev. of Saturday, by lan McEwan. New York Review of Books 26 May 2005: 8-9.

Borradori, Giovanna. Philosophy in a Time of Terror: Dialogues with Jürgen Habermas and Jacques Derrida. Chicago: U of Chicago P, 2003.

Currie, Mark. About Time: Narrative, Fiction, and the Philosophy of Time. Edinburgh: Edinburgh UP, 2007.

DeLillo, Don. Falling Man. New York: Scribner, 2007.

---. "In the Ruins of the Future: Reflections on Terror and Loss in the Shadow of September." Harper's Dec. 2001: 33-40.

Duvall, John N. "Witnessing Trauma: Falling Man and Performance Art." Don DeLillo: Mao II, Underworld, Falling Man. Ed. Stacey Olster. London: Continuum, 2011. $152-68$.

Eaglestone, Robert. "'The Age of Reason Was Over ... An Age of Fury Was Dawning': Contemporary Fiction and Terror." Terror and the Postcolonial. Ed. Elleke Boehmer and Stephen Morton. Malden, MA: Wiley-Blackwell, 2010. 361-69.

Foucault, Michel. Discipline and Punish: The Birth of the Prison. Trans. Alan Sheridan. New York: Vintage, 1979.

---. "The Subject and Power." The Essential Foucault: Selections from Essential Works of Foucault, 1954-1984. Ed. Paul Rabinow and Nikolas Rose. New York: New Press, 2003. 126-44.

---. "What is Enlightenment?" The Essential Foucault: Selections from Essential Works of Foucault, 1954-1984. Ed. Paul Rabinow and Nikolas Rose. New York: New Press, 2003. 43-57.

Gray, Richard. "Open Doors, Closed Minds: American Prose Writing at a Time of Crisis." American Literary History 21.1 (Spring 2009): 128-51.

Gutting, Gary. "Michel Foucault: A User's Manual." The Cambridge Companion to Foucault. Ed. Gary Gutting. Cambridge: Cambridge UP, 1994. 1-27. 
Hadley, Elaine. "On a Darkling Plain: Victorian Liberalism and the Fantasy of Agency." Victorian Studies 48.1 (2005): 92-102.

Hamid, Mohsin. The Reluctant Fundamentalist. Orlando: Harcourt, 2007.

Hutcheon, Linda. A Poetics of Postmodernism: History, Theory, Fiction. New York: Routledge, 1988.

Jameson, Fredric. Postmodernism, or, The Cultural Logic of Late Capitalism. Durham: Duke UP, 1991.

Kaplan, Amy. "Homeland Insecurities: Transformations of Language and Space." September 11 in History: A Watershed Moment? Ed. Mary L. Dudziak. Durham: Duke UP, 2003. 55-69.

Kauffman, Linda S. "The Wake of Terror: Don DeLillo's 'In the Ruins of the Future,' 'Baader-Meinhof,' and Falling Man." Modern Fiction Studies 54.2 (Summer 2008): 353-77.

McEwan, lan. Saturday. 2005. London: Vintage, 2006.

Rothberg, Michael. "A Failure of the Imagination: Diagnosing the Post-9/11 Novel: A Response to Richard Gray." American Literary History 21.1 (Spring 2009): 15258.

Schechner, Richard. "9/11 as Avant-Garde Art?" PMLA 124.5 (October 2009): 1820-29. Versluys, Kristiaan. Out of the Blue: September 11 and the Novel. New York: Columbia UP, 2009.

Wegner, Phillip E. Life Between Two Deaths, 1989-2001: U.S. Culture in the Long Nineties. Durham: Duke UP, 2009.

Žižek, Slavoj. First as Tragedy, Then as Farce. London: Verso, 2009.

---. Iraq: The Borrowed Kettle. London: Verso, 2004.

---. The Sublime Object of Ideology. London: Verso, 1989.

---. Welcome to the Desert of the Real! Five Essays on September 11 and Related Dates. London: Verso, 2002. 